J. Asiat. Soc. Bangladesh, Sci. 39(1): 35-41, June 2013

\title{
SURVEY ON THE INCIDENCE AND SEVERITY OF COMMON SCAB OF POTATO IN BANGLADESH
}

\author{
NAJMUN NAHER ${ }^{1}$, MOHAMMAD HOSSAIN ${ }^{2}$ AND M. A. BASHAR ${ }^{3}$ \\ ${ }^{I}$ Department of Botany, Life \& Earth Science Group, National University, \\ Gazipur-1704. \\ ${ }^{2}$ Tuber Crop Research Centre, Bangladesh Agricultural Research Institute, \\ Gazipur, Bangladesh \\ ${ }^{3}$ Department of Botany, University of Dhaka, Dhaka-1000, Bangladesh
}

\begin{abstract}
A survey on the incidence and severity of common scab (Streptomyces sp.) of potato was made in the major potato growing districts of Bangladesh during the cropping season of 2007-2008. A total of 150 fields was surveyed for collection of potato common scab infected samples. It was observed that there was a lot of variation in disease severity and its incidence in different districts of Bangladesh. Highest per cent scab incidence (71.41 \%) was recorded in Kahalo Upazila (Bogra) and lowest (13.79 \%) in Pirgacha Upazila (Rangpur). Disease incidence also varied among the tested varieties namely, Cardinal, Diamant, Granola, Binella and Raja. Highest incidence was observed in Cardinal (54.08 $\%$ ) followed by Binella $(50.71 \%)$ and it was lowest in Raja $(3.07 \%)$. Cardinal and Binella were found to be highly susceptible and Raja was resistant to common scab disease. Diamant, the commercial variety showed medium susceptible reaction to the disease.
\end{abstract}

Key words: Survey, Incidence, Common scab, Potato, Bangladesh

\section{Introduction}

Potato, the world's fourth most important food crop after wheat, maize and rice, provides balanced source of starch, vitamins and minerals to many communities in the global villages (Rowe 1993). In Bangladesh potato is the third largest crop after rice and wheat. It is used primarily as a vegetable and has potential as a staple food. Potato cultivation in the Bengal was promoted by a British Governor in 1770 s and then it was a well established garden vegetable. Annual consumption of potato has been growing rapidly, from around $7 \mathrm{~kg}$ per capita in 1990 to more than $25 \mathrm{~kg}$ in 2005 (FAO 2007).

In Bangladesh, so far as many as 57 diseases in potato have been recorded (Hossain et al. 2008). Among them late blight, stem rot /sclerotium rot, wilt, common scab, potato leaf roll and mosaic are the most important diseases (Ahmed et al. 2000). Common scab is widely distributed in Bangladesh which gives ugly appearance to wear potatoes. Though the disease does not cause appreciable reduction in yield, it can cause great loss due to reduction of market value of tuber (Dutt 1997). Moreover, infected seed tubers serve as the primary sources of inoculum for the next season (Anonymous 2009). 
The incidence, severity, etiology, epidemiology and control of common scab have been investigated extensively in many countries of the world and the disease has been the topic of various reports in Bangladesh during the end of the $18^{\text {th }}$ century (Rahman 1990). In Bangladesh potato common scab was initially a minor disease but now has become a major potato disease and incidence of the disease is increasing day by day. The information of potato common scab is not available on the incidence of disease and its severity in different agro- ecological regions and the susceptibility of commercially cultivated potato in Bangladesh. Keeping all these in view, the present investigation was undertaken to study the regional variations on the disease incidence, severity and susceptibility of common scab disease of commercially cultivated potato in Bangladesh.

\section{Materials and Methods}

Fifteen Upazilas, three from each district of Bogra, Rangpur, Rajshahi, Munsiganj and Comilla were selected for the survey. The Upazilas and districts located into eight different Agro-ecological zones of Bangladesh (Anonymous 2005). The disease incidence (DI), disease severity (DS) and percentage of disease index (PDI) were recorded during the potato harvesting season of December 2007 to February 2008. The sampling areas are shown in Fig 1.

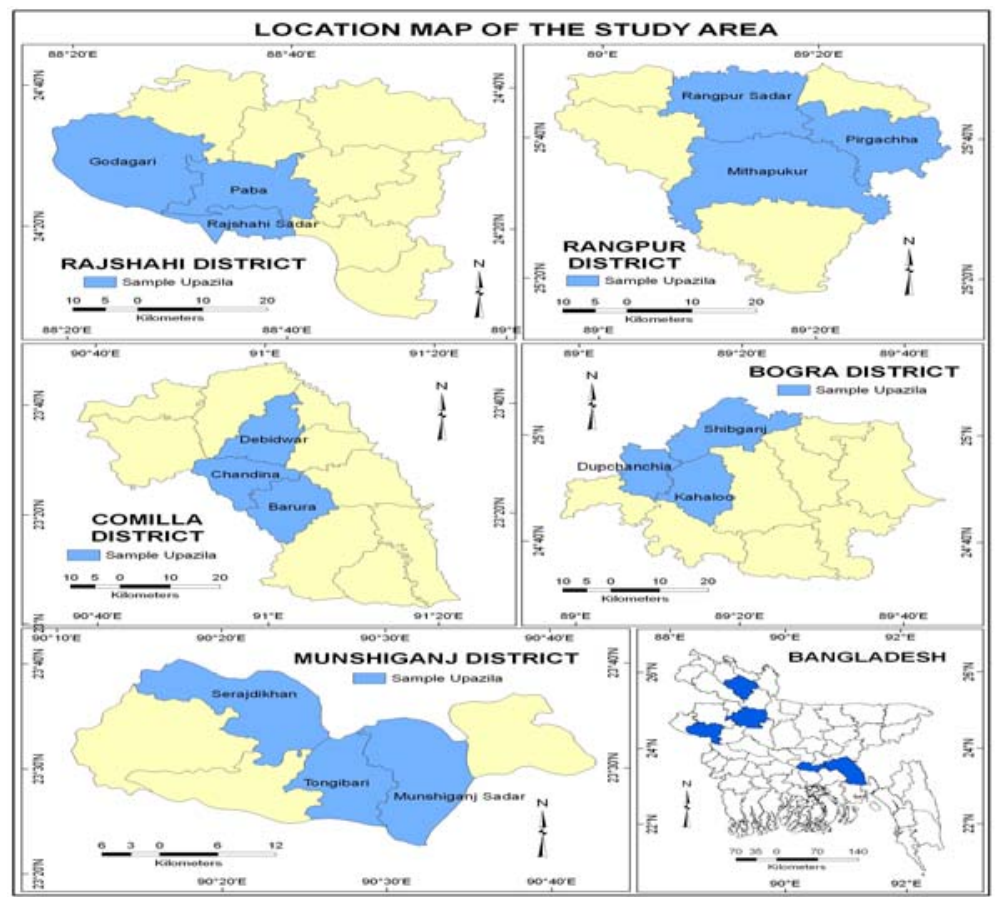

Fig. 1. Location map of the study area for common scab disease incidence in Bangladesh. 
Three Upazilas from each district and ten potato fields from each Upazila were randomly selected. Therefore, a total of 150 fields was selected for sampling during potato harvesting season. During the survey, ten sampling points from a field were selected. In each point ten tubers were collected at random and composite it. Therefore, a total of 100 tubers from each field was collected for observation. Cultivars grown in selected fields were also recorded.

Disease incidence was calculated on the basis of number and weight of infected tubers and it was expressed in percentage. Disease severity was recorded based on the symptom as shown on the surface of the tuber. One hundred tubers were selected randomly, categorized into 0-5 scale (Liu et al. 1995) and finally percentage of disease incidence was calculated following the formula of Goswami et al. (2002). Disease severity was recorded according to disease severity rating scales where $0=$ No symptom, $1=$ Very small lesions, $2=$ Small superficial lesions, $3=$ Periderm broken, $4=$ Light pitted and $5=$ Deep pitted.

Randomly selected potato cultivars were grouped as least susceptible, medium susceptible, highly susceptible and comparatively resistant. Grouping of potato cultivars was done based on the potato common scab index. Average PDI value of each potato variety was calculated and then the class was determined. Susceptibility of potato cultivars to common scab was grouped according to Marais and Vorster (1988) which is given below:

Scab Index
$<08$
$08-15$
$15-20$
$20-24$
$>24$

\section{Class}

Comparatively resistant

Least susceptible

Medium susceptible

Highly susceptible

Very highly susceptible

\section{Results and Discussion}

Under field condition common scab of potato was identified by observing the symptoms of the disease. The disease was found to produce different types of symptoms on the surface of the tubers. The lesions appear as small reddish brown, water- soaked lesions on the tuber periderm. As the pathogen continues to colonize the tuber, the host develops wound periderm resulting in slightly raised lesions composed of rough and corky tissues. These spots coalesce to form irregularly shaped patches which are usually tan to brown in color and rough in texture. The patches became cracked as the infection progresses and developed a star-like appearance. In deeper lesions, the tuber periderm was ruptured. Typical lesions on susceptible potato variety are presented in Plate 1. 


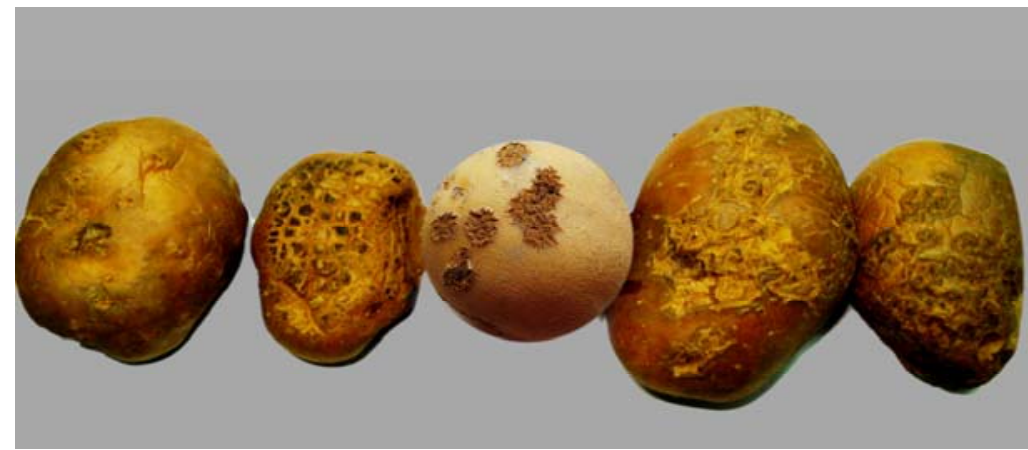

Plate 1. Lesion types of common scab on potato tubers.

The percentage of disease incidence of potato tubers is represented in Table 1 based on number and weight. Disease incidence in number and weight basis was highest at Kahaloo (73.3 and $71.41 \%)$ and lowest (13.6 and $13.79 \%)$ at Pirgacha. Disease incidence at Kahaloo was followed by Paba (67.9 and 69.40\%), Shibganj (61.3 and $61.72 \%$ ) and Dhupchaciya (56.0 and $55.32 \%$ ). The disease incidence at Chandina and Mithapukur were 22.23 and $28.70 \%$ respectively (Table 1).

Table 1. Prevalence and severity of common scab of potato in fifteen Upazilas of five districts during potato harvesting season in 2007- 2008 .

\begin{tabular}{|c|c|c|c|c|c|}
\hline District & Upazila & $\begin{array}{l}\text { Disease Incidence } \\
(\%) \text { of infected } \\
\text { tuber by No. }\end{array}$ & $\begin{array}{l}\text { Disease Incidence } \\
(\%) \text { of infected } \\
\text { tuber by Wt. }\end{array}$ & $\begin{array}{c}\text { Range (\%) of } \\
\text { infected tuber } \\
\text { by wt. }\end{array}$ & PDI \\
\hline \multirow{3}{*}{ 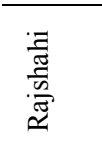 } & Paba & 67.9 & 69.40 & $26-95$ & 22.52 \\
\hline & Godagari & 31.4 & 37.15 & $7-55$ & 15.04 \\
\hline & $\begin{array}{l}\text { Rajshahi } \\
\text { sadar }\end{array}$ & 41.90 & 46.88 & $18-64$ & 22.78 \\
\hline \multirow{3}{*}{$\begin{array}{l}\frac{\pi}{0} \\
0 \\
0 \\
0\end{array}$} & Dhupchaciya & 56.0 & 55.32 & $43-66$ & 15.06 \\
\hline & Shibganj & 61.3 & 61.72 & $29-100$ & 24.44 \\
\hline & Kahaloo & 73.3 & 71.41 & $37-100$ & 28.76 \\
\hline \multirow{3}{*}{ 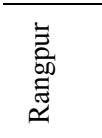 } & Pirgacha & 13.6 & 13.79 & $04-31$ & 3.64 \\
\hline & Mithapukur & 26.8 & 28.70 & $13-47$ & 9.62 \\
\hline & $\begin{array}{l}\text { Rangpur } \\
\text { sadar }\end{array}$ & 38.3 & 44.11 & $20-78$ & 13.02 \\
\hline \multirow{3}{*}{  } & $\begin{array}{l}\text { Munsiganj } \\
\text { sadar }\end{array}$ & 24.1 & 31.68 & $9-44$ & 8.26 \\
\hline & Tongibari & 29.6 & 32.88 & $10-68$ & 11.4 \\
\hline & Serajdekhan & 27.9 & 32.91 & $18-40$ & 10.82 \\
\hline \multirow{3}{*}{ 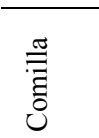 } & Barura & 41.6 & 47.29 & $17-90$ & 23.9 \\
\hline & Chandina & 21.4 & 22.23 & $9-75$ & 12.9 \\
\hline & Dabedhar & 40.9 & 45.38 & $16-56$ & 24.28 \\
\hline
\end{tabular}


Highest scab incidence was observed in Cardinal (54.08 \%) followed by Binella (50.71 $\%$ ) and both the varieties were highly susceptible to common scab disease. Diamant was medium susceptible potato variety where the incidence to common scab was $40.96 \%$. The incidence of common scab in Granola was $38.96 \%$. Lowest scab incidence was recorded in Raja (3.07 \%) which showed resistant reaction (Table 2).

Table 2. Scab index and incidence of potato cultivars screened in 2008 at farmer's field.

\begin{tabular}{lccl}
\hline Cultivar`s name & Scab index & Scab incidence $(\%)$ & \multicolumn{1}{c}{ Class } \\
\hline Diamant & 16.955 & 40.96 & Medium susceptible \\
Cardinal & 22.955 & 54.08 & Highly susceptible \\
Granola & 13.072 & 38.96 & Least susceptible \\
Binella & 13.044 & 50.71 & Highly susceptible \\
Raja & 0.800 & 03.07 & Comparatively resistant \\
\hline
\end{tabular}

From the Fig. 2 it is apparent that among the surveyed districts the highest scab incidence was recorded in Bogra (62.81\%) and lowest in Rangpur (28.86 \%). The scab incidence was 51.14, 38.3, and 32.49\% in Rajshahi, Comilla and Munsiganj respectively. The highest percentage of disease index (PDI) was also recorded in Bogra (22.75\%) followed by Comilla (20.36\%), Rajshahi (20.11\%) and Munsiganj (10.16\%). Lowest PDI was recorded in Rangpur (8.76\%).

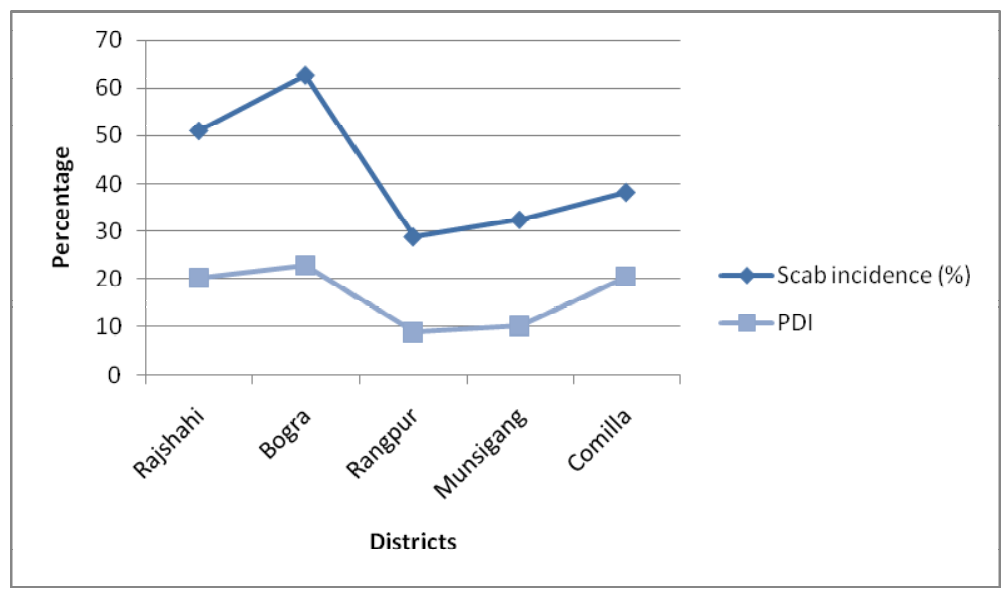

Fig. 2. Percentage of scab incidence and disease index of five districts.

Scab incidence and PDI were higher in Rajshahi and Bogra districts. Higher scab incidence in Rajshahi and Bogra might be due to cultivation of susceptible variety viz. Cardinal, Diamant and Granola. Mono- crop (potato) cultivation in these districts might 
be another reason for increasing inoculam pressure of this disease. The pathogen survives as spores or mycelium within crop debris. It can remain viable in soil from a decade to up to 20 years (Kritzman et al. 1996).

High soil $\mathrm{pH}$ is favorable for scab disease incidence. High soil $\mathrm{pH}$ (above 7) is present in Rajshahi and Bogra districts. The soil pH level of Rangpur, Munsigang and Comilla districts are 4.6, 4.7 and 4.1 respectively (Anonymous 2005). Both the disease incidence and PDI were higher in Rajshahi and Bogra districts compared to Rangpur, Munsigang and Comilla districts. Disease development increases with soil $\mathrm{pH}$ from 5.0 to 8.0 (Goto 1985). The variation of the occurrence of scab and its severity in different districts of Bangladesh might be due to cropping system, soil moisture, soil texture and soil $\mathrm{pH}$ (Loria 1991).

From this survey it appears that the occurrence of common scab and its severity varies from fields to fields and locations to locations. It was also observed that the most popular variety Diamant and Cardinal showed medium susceptible and highly susceptible reaction to common scab disease respectively which indicates the necessity of finding out suitable control measures of the disease. An integrated disease management approach that includes cultural, biological and chemical control methods, in the field and in storage, may be necessary for long-term control of common scab disease. Research should also be undertaken in order to develop resistant variety against scab disease.

\section{References}

Ahmed, H.U., M.S. Ali and T.K. Dey. 2000. Tuber crop disease management. Poster presented in the International Conference on Integrated Plant Disease Management for Sustainable Agriculture. Mitra DK (ed), Indian Phytopathological Society, New Delhi, India. 3: $1281 \mathrm{p}$.

Anonymous. 2005. Fertilizer recommendation guide. BARC. Soil publications No. 45.

Anonymous. 2009. Annual report. Tuber Crops Research Centre, BARI, Gazipur, Bangladesh. $204 \mathrm{p}$

Dutt, B.H. 1997. Bacterial and fungal diseases of potato. ICAR, New Delhi. $196 \mathrm{p}$

FAO. 2007. Food and Agricultural Organization of the United Nations. Rap. Pub. $71 \mathrm{p}$

Goswami, B.K., M.I. Zahid and M.Q. Haq. 2002. Screening of Colocasia esculenta germplasm to Phytophthora leaf blight. Bangladesh J Plant Pathol. 9 (1-2): 21-24.

Goto, K. 1985. Relationship between soil pH, available calcium and prevalence of Potato scab. Soil Science and Plant Nutrition. 31: 411-418.

Hossain, M., T.K. Dey, S. Akhter, M.K.R. Bhuiyan, M.A. Hoque, B.C. Kundu, M.A. Hossain and S.N. Begum. 2008. Activities and achievements of Tuber Crops Research Centre at a glance. Tuber Crops Research Centre, Bangladesh Agricultural Research Institute, Joydebpur, Gazipur-1701. 23 p

Kritzman, G., A. Shain-Kahani, B., Kirshner, Y., Bar, Z. Riven, J. Katan and A. Grinstein 1996. Potato wart disease of peanut. Phytoparasitica. 24: 293-304.

Liu, D., N. A. Anderson and L. L. Kinkel. 1995. Biological control of potato scab in the field with antagonistic Streptomyces scabies. Phytopathology. 85: 827-831. 
Loria, R. 1991. Potato scab factsheet. Vegetable MD online. Cornell University, http://vegetablemdonline.ppath.cornell.edu/factsheets/Potato_Scab.htm.

Marais, L. and R. Vorster. 1988. Evaluation in pot and field trials for resistance of potato cultivars and breeding lines to common scab caused by Streptomyces scabies. Potato Res. 31: 401-404.

Rahman, A. 1990. Potato and sweet potato in Bangladesh. Working paper series, March 1990. The CGPRT centre.

Rowe, R.C. 1993. Potato health management: a holistic approach. In: Potato Health Management. Rowe RC (ed). Am Phytopathol Soci St. pp. 154-156.

(Received revised manuscript on 20 May 2013) 